\title{
Review
}

\section{Guaraná's Journey from Regional Tonic to Aphrodisiac and Global Energy Drink}

\author{
Nigel Smith ${ }^{1}$ and André Luiz Atroch ${ }^{2}$ \\ ${ }^{1}$ Department of Geography, PO Box 117315, University of Florida, Gainesville, FL 32611-7315, USA and \\ 2EMBRAPA Amazônia Occidental, Manaus, Amazonas, Brazil
}

\begin{abstract}
Guaraná (Paullinia cupana H.B.K., Sapindaceae) is a rainforest vine that was domesticated in the Amazon for its caffeine-rich fruits. Guaraná has long been used as a tonic and to treat various disorders in Brazil and abroad and became a national soda in Brazil about a century ago. In the last two decades or so, guaraná has emerged as a key ingredient in various 'sports' and energy drinks as well as concoctions that allegedly boost one's libido. For some time, guaraná's high caffeine content was thought to be a detriment because of health concerns about excessive intake of caffeine-rich drinks. But it is precisely this quality, and the fact that it has a mysterious name and comes from an exotic land, that has propelled guaraná into a global beverage.
\end{abstract}

Keywords: Amazonia-aphrodisiac-ethnopharmacology-guaraná-medical history-Paullinia cupana-xanthines

\section{Introduction}

Guaraná seeds contain more caffeine than any other plant in the world with levels ranging from 2 to $7.5 \%$ (1). Guaraná contains about four times as much caffeine as coffee. Some 60 plant species contain caffeine, including coffee, distributed among seven plant families. Guaraná seeds also contain traces of theobromine and theophylline, other alkaloids in the xanthine group (2). The evolutionary 'purpose' of the xanthines is unclear, but they may help protect the plants from attack by insect pests, herbivores and pathogens. In humans, xanthines stimulate the central nervous system, increase secretion of gastric acid and serve as a bronchodilator and a diuretic.

Caffeine is also addictive, although it is not classified as a 'drug' by government agencies charged with sorting out which plants and synthetic compounds are deemed a public menace. Ironically, guaraná's high caffeine levels were once thought to be a detriment in promoting guaraná outside of Brazil because of health concerns

For reprints and all correspondence: Prof. Nigel Smith, Department of Geography, PO Box 117315, University of Florida, Gainesville,

FL 32611-7315, USA. E-mail: nsmith@geog.ufl.edu about excessive caffeine consumption, but now this attribute has turned out to be a marketing asset. This article traces how an ancient remedy for a variety of ailments has been distorted by market forces into an aphrodisiac and energy booster, often concocted with 'medicinal' herbs and vitamins.

\section{Origins and Early Medicinal Uses}

Guaraná was domesticated in the interfluvial forests between the lower Tapajós and lower Madeira in the Brazilian Amazon. It is unclear which indigenous group domesticated guaraná, but the Sateré-Maué who live along the Maués River and its affluents cultivate guaraná extensively and have incorporated the plant in their mythology. A Sateré-Maué myth recounts how guaraná sprung from the eye of a boy who had been murdered (3); indeed guaraná fruit resembles an human eye when it ripens and the red skin and underlying white mesocarp split to reveal a black, iris-like seed.

Guaraná has long been esteemed for its energetic and curative properties. In the late 17th century, for example, the Jesuit missionary João Felipe Betendorf noted that 
the Sateré-Maue (then known as the Andirazes) valued guaraná as much as Europeans did gold because the drink gave them 'so much energy, that when hunting, they could go from one day to the next without feeling hungry' (4). Father Betendorf noted that guaraná was drunk to diminish fevers and cure headaches, and also served as a powerful diuretic. On the latter he remarked that 'With respect to its reputation for provoking the need to urinate, I can personally testify.'

During the colonial period, guaraná was sold variously as a fortifier, stimulant, tonic, antidote to fever, a preventive against hardening of the arteries and to treat migraines. Guaraná was deemed especially effective in treating diarrhea and dysentery $(5,6)$. But as with any product, overindulgence can trigger problems. Over two centuries ago, Francisco Xavier Ribeiro de Sampaio, a Brazilian judge, warned that excessive drinking of guaraná can lead to insomnia and even impotence (7). In the middle of the 18th century while visiting Santarem along the middle Amazon, the fourth Bishop of Belém, Dom João de São José de Queirós da Silveira greatly appreciated guaraná but warned that excessive consumption could lead to insomnia or dizziness (8).

\section{Cultivation and Processing}

Guaraná is grown on small and large farms, either as a monocrop or alongside other crops. Guaraná is harvested by hand in the dry season. If the entire fruit bunch is ripe, it is either snipped off with scissors or small pruning shears, or broken off manually. If only a few berries are ripe, they are picked individually. The guaraná fruits are then placed in a basket and carried back to the home. Before roasting the seeds, the red skin must be removed. The fruits are skinned by hand, left to soak in water, or simply stored for several days until the skin softens.

On small farms in the Maués watershed, guaraná seeds are roasted on a griddle, preferably of clay to reduce the chances of burning. Clay griddles are about two meters in diameter and are made at various households along the Maués and some of its affluents, wherever suitable clay is found. Guaraná seeds are roasted in an open-sided hut, but it is hot work and it takes several hours. Women roast guaraná in Sateré-Maué society; they periodically stop stirring the seeds to pick some up and smell them to see if they are ready to come off the griddle. The toasted seeds are then pounded in a wooden mortar, mixed with water and then molded into cylinders (bastão) before drying in the sun. They are then smoked in specialized huts for several weeks to impart a unique flavor. The smoked cylinders last up to a year, whereas powdered guaraná loses some of its flavor after a few months (9). Industrial plants grind the roasted beans with machinery similar to that used for processing coffee.

\section{Evolution of Guaraná Beverages in Brazil}

To prepare the traditional guaraná beverage, the hard cylinder is grated with the bony tongue of the pirarucu (Arapaima gigas), one of the largest fish in the Amazon, or a small piece of flat rough stone, such as sandstone (10). The powder either collects on a piece of paper or falls directly into a calabash gourd containing water. The Sateré-Maué call the tan-colored guaraná drink çapó (11). In Sateré-Maué culture, only women prepare guaraná for drinking, whereas among non-indigenous folk, both men and women grate the cylinders. For more formal occasions, the Sateré-Maué use a small, hour glassshaped stand (patuai), fashioned from forest vines, to support the calabash bowl when grating guaraná. The host and guests then pass the bowl around and periodically place it back on the stand. Urban and rural folk in the Maués watershed typically take guaraná upon rising and wait an hour or two before a breakfast of black coffee and crackers or bread.

Guaraná was transformed from an elixir and home-prepared beverage to a mass-produced soda in the early 20th century. The emergence of ice-making machines further propelled the soda industry in Brazil and elsewhere in the early 1900s. São Paulo-based Antarctica that merged in 1999 with Brahma to form AmBev and was in turn purchased by InBev, a Belgian company, in 2003, introduced carbonated guaraná to Brazilians in 1909. At first, guaraná soda was sold mainly in southern Brazil, but many independent bottlers began making their own versions all over Brazil. In the Brazilian states of Amazonas and Bahia, guaraná pushups became popular among poorer folk in urban areas as soon as refrigeration became widespread in the mid-20th century known as dindin or chopp.

\section{Emergence of Guaraná as an Aphrodisiac}

In the last decade or so, guaraná carts have begun appearing in some street markets in the Brazilian Amazon, such as Belém, Abaetetuba, Manaus and Manacapuru. Such carts sell guaraná beverages prepared in a blender with crushed ice. The formula for the energy drink varies among vendors, but generally contains nuts, such as cashew, peanuts or Brazil nuts, powdered milk, aphrodisiac roots or barks and guaraná powder or syrup. Some add fruit, such as avocado or raw quail eggs. Guaraná smoothies prepared on ambulant carts as well as in some cafés in the Brazilian Amazon are uplifting and fulfilling, similar in texture and effect to a frappuccino served in espresso cafés in North America.

One company has also employed guaraná in a concoction with 'love herbs for good staying power'. It contains a 'mixture of exotic South American herbs', including damiana (Turnera diffusa Willdenow et Schultes; a Central American herb used to make 
aphrodisiac beverages), schizandra (Schisandra chinensis (Turcz.) Baill; a vine from northeastern China and Japan thought to have immune-enhancing properties), guaraná, and maté (Ilex paraguayensis A. St.-Hil.), a temperate to subtropical tree in South America with leaves used for making a tea (12).

\section{Energy Drinks and the Globalization of Guaraná}

Energy drinks, which often contain guaraná, have emerged as a boom sector in the global soda industry. The fact that the boom in guaraná-containing drinks has not spurred much increase in the area devoted to the crop is one indication that beverage manufacturers are being quite parsimonious in the amount of guaraná they are using in their products. The state of Amazonas in Brazil typically produces only 700-800 tons of guaraná seeds a year with little noticeable upward trend. The Brazilian Amazon is responsible for roughly a third of the guaraná produced in Brazil, so national production is less than three thousand tons of dried guaraná seed a year. The globalization of guaraná beverages is thus not benefiting the Amazon much as has happened in the past with other booms, such as rubber extraction in the late 19th century and early 20th century.

Dozens of new energy drinks containing guaraná are reaching the shelves of supermarkets, gas stations and convenience stores every year. Both multinational corporations and small, independent companies have ventured into the fray. Many of the names given the guaraná-containing beverages evoke energy. Indeed, the label on one drink claims that for indigenous peoples guaraná 'was a primal source of energy from the Amazon jungle'.

The formula of energy drinks with guaraná varies between product lines and even over time with the same product name, but usually contains one or more of the following plants: gingko biloba, ginseng, maté, Echinacea (taken by some in the belief that it prevents or reduces the severity of colds) and yohimbe (Pausinystalia yohimba Pierre ex Baille). Other ingredients range from bee pollen to fruit juices, arginine (a non-essential amino acid that allegedly boosts the immune system and promotes muscle growth), zinc and creatine (a dietary supplement taken by some to increase muscle mass).

\section{Medical Concerns}

The dramatic increase in beverages containing guaraná and other sources of caffeine has stirred some concern in the medical community. Already some young people have been admitted to emergency rooms suffering from overdoses of caffeine after overindulging. The increased consumption of caffeine beverages and pills is a symptom of modern life which leaves insufficient time for a good night's sleep. Moderate consumption of drinks containing caffeine might alleviate drowsiness for a while, but it cannot replace the need for sleep. Little evidence suggests that caffeine intake boosts performance in sports or in the bedroom. Proper hydration and adequate rest as well as paying attention to diet and regular exercise are likely to prove more helpful.

Guaraná is known to help stave off hunger and it is used by people trying to lose weight. But almost all energy drinks with guaraná as one of the ingredients also contain large amounts of high fructose corn syrup, a sure sign that the beverages are not particularly healthy and may lead to weight gain when taken on a regular basis. Only a few of the energy drinks containing guaraná have diet versions. Guaraná powder contains negligible calories but is bitter. Most people who consume guaraná products outside of the traditional area of consumption are drinking highly sugared beverages. Improved eating habits and increased exercise as part of a transformed life style are better bets for keeping the weight off.

\section{Prospects for Guaraná}

Sales of products containing guaraná are likely to continue soaring in spite of some medical concerns. The stimulating effects of guaraná are longer lasting than coffee because the caffeine in guaraná apparently binds with tannins (16). Guaraná also has the luster of an exotic rainforest vine with a long history of use as a medicinal plant. Curiously, guaraná was consumed in the United States and Europe in the 18th and 19th century, and then dropped from the pharmacopeias in those regions until the late 20th century when it re-emerged in carbonated energy drinks, aphrodisiac concoctions and stay alert pills. The success of such guaraná products may provide momentum for soda manufacturers to launch guaraná soda in industrial nations, perhaps with a stronger concentration of syrup typical of the robust sodas produced by local companies in Manaus, Brazil.

\section{References}

1. Beck HT. Caffeine, alcohol, and sweeteners. In: Prance GT (ed). The Cultural History of Plants. New York: Routledge, 2005, 173-90.

2. Pizza C, Rastrelli L, Totaro K, De Simone F. Paullinia cupana (guaraná) determinazione degli alcaloidi xantinici per la valutazione della qualitá di prodotti base di guaraná. In: Il Guaraná degli Indios Sateré-Maué, Istituto Italo-Latinoamericana, Rome: Serie Scienza 13, 1999, 13-22.

3. Pereira N. Os Índios Maués. Organização Simões, Rio de Janeiro, 1954.

4. Betendorf JF. Chronica da missão dos padres da Companhia de Jesus no Estado do Maranhão. Revista do Instituto Historico e Geographico Brazileiro 1909;72:1-682.

5. Steinen, K von den. Durch Central-Brasilien: Expedition zur Erforschung des Shingú im Jahre 1884. Brockhaus, Liepzig, 1886.

6. Castelnau, F. Éxpedition dans les Parties Centrales de l'Amérique du Sud, de Rio de Janeiro à Lima, et de Lima au Pará, pendant les Années 1843-1847. Vol. 2, Paris: Bertrand, 1850. 
7. Sampaio, FXR. Diário da Viagem que em Visita, e Correição, das Povações da Capitania de S. Joze do Rio Negro fez o Ouvidor, e Intendente Geral da Mesma, no Anno de 1774 e 1775. Lisbon: Typographia da Academia, 1825.

8. Queirós da Silveira J. Viagem e visita do sertão em o Bispado do Gram-Pará em 1762 e 1763. Revista Trimensal de História e Geografia 1847;9:43-527.

9. Henman AR. Guaraná (Paullinia cupana var. sorbilis): ecological and social perspectives on an economic plant of the central Amazon basin. J Ethnopharmacol 1982;6:311-38.

10. Leacock S. Economic life of the Maue Indians. Boletim do Museu Paraense Emilio Goeldi (Nova Série, Antropologia) 1964;19:1-30.
11. Monteiro MY. Antropogeografia do Guaraná. Instituto Nacional de Pesquisas da Amazônia, Cadernos da Amazônia, No. 6, Manaus, 1965.

12. Tremble, Coca-Cola, tremble. The Economist, March 24, 2001, p. 35.

13. www.ampenergy.com

14. www.rockstar69.com/ingredients.html

15. www.sobenofear.com/huh/nofear.shtml

16. Rätsch C. The Encyclopedia of Psychoative Plants: Ethnopharmacology and its Applications. Rochester, Vermont: Park Street Press, 2005.

Received May 13, 2007; accepted September 12, 2007 


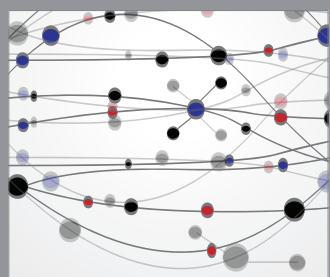

The Scientific World Journal
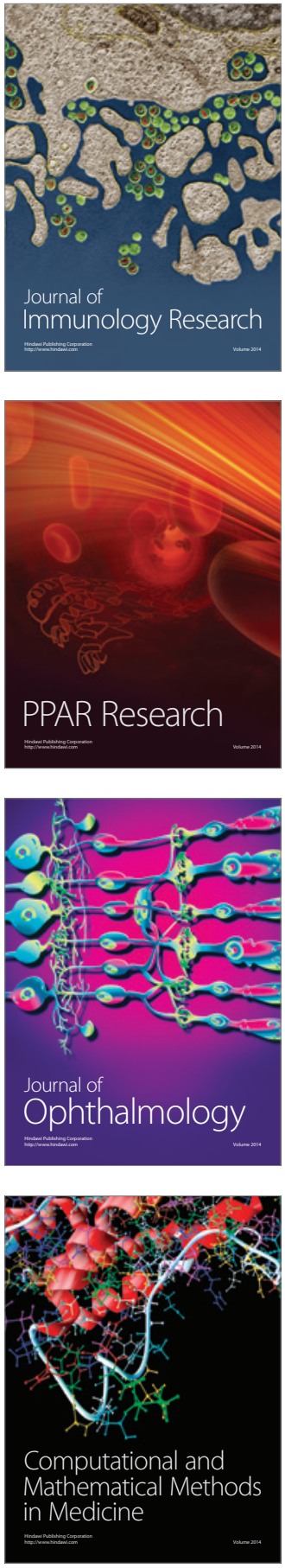

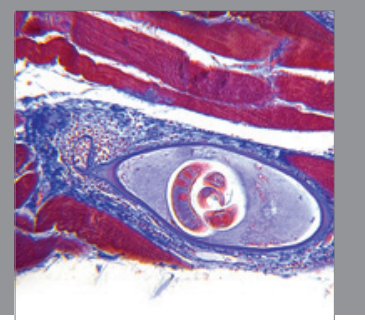

Gastroenterology

Research and Practice
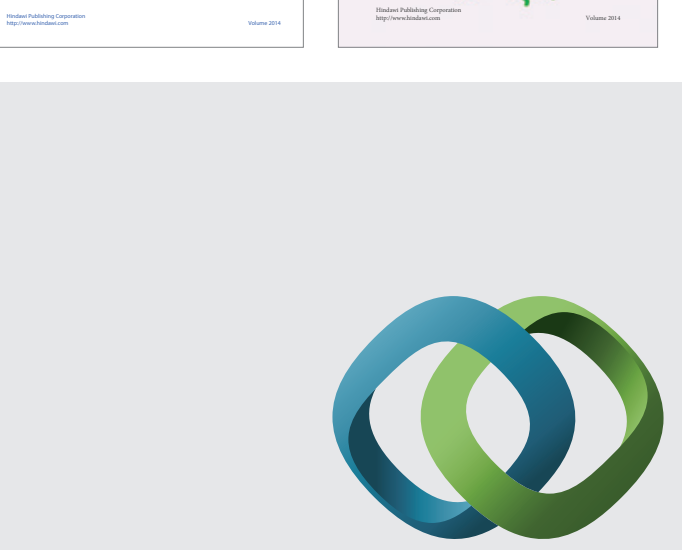

\section{Hindawi}

Submit your manuscripts at

http://www.hindawi.com
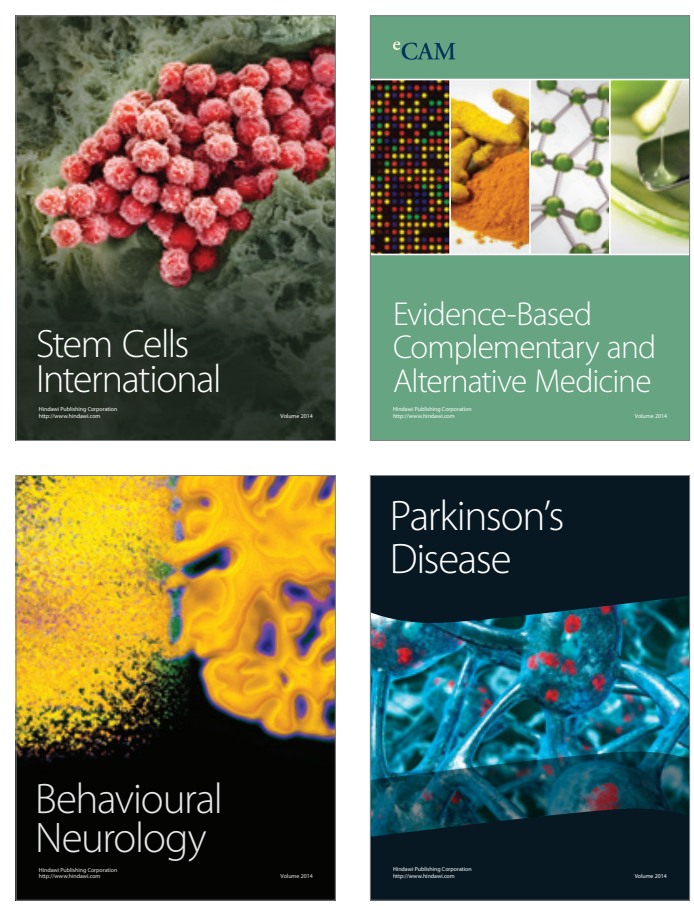

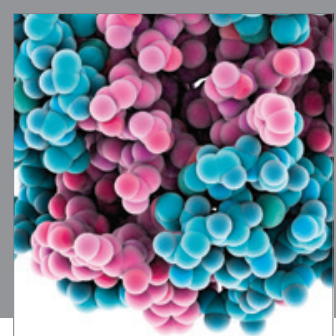

Journal of
Diabetes Research

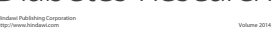

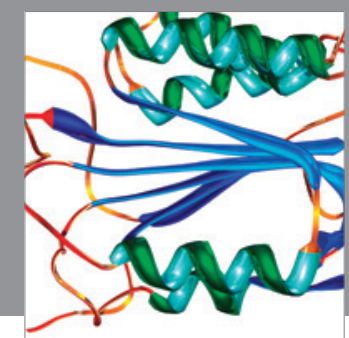

Disease Markers
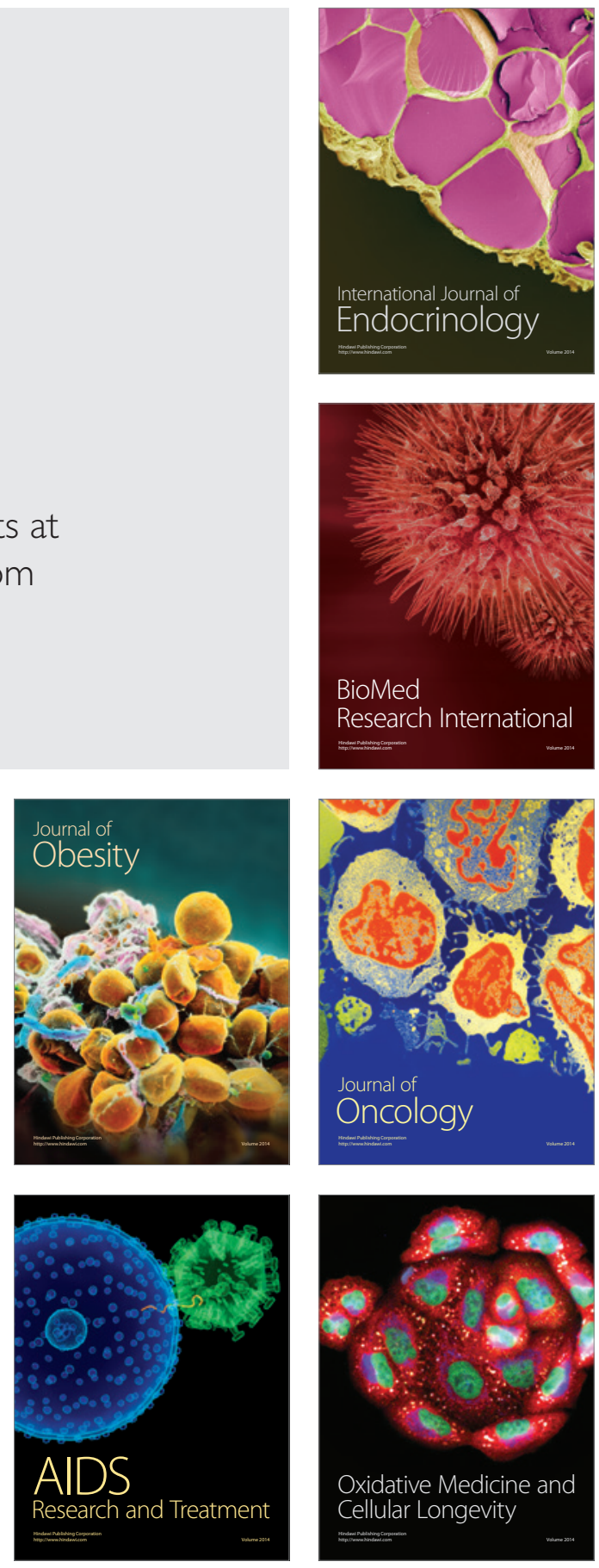